\title{
Production of Polyclonal Antibodies to a Recombinant Potato Mop-top Virus Non-structural Triple Gene Block Protein 1
}

\author{
N. Čeřovská, M. Filigarová and T. PeČenková \\ Author's address: Institute of Experimental Botany, Academy of Sciences of the Czech Republic, Na Karlovce 1a, 16000 \\ Prague 6, Czech Republic (correspondence to N. Čřrovská. E-mail: cerovska@ueb.cas.cz) \\ Received December 20, 2005; accepted March 1, 2006
}

Keywords: Potato mop-top virus, recombinant protein, triple gene block, polyclonal antibodies

\begin{abstract}
The gene encoding the triple gene block protein 1 (TGBp1) of Potato mop-top virus (PMTV) was cloned into expression vector pQE32 tagging the protein with $6 \mathrm{xH}$ is on the N-terminus. When the gene was enshortened on its $3^{\prime}$-end by two different restriction digestions, efficient and high yield bacterial expression was achieved in both cases, as shown by sodium dodecyl sulphate polyacrylamide gel electrophoresis (SDS-PAGE) and Western blot. One of these two constructs was used for raising rabbit polyclonal antibodies. The obtained sera and antibodies were tested for the detection of PMTV in laboratory host Nicotiana benthamiana and natural host Solanum tuberosum by enzyme-linked immunosorbent assay (ELISA) as well as by Western blots. The obtained antisera are more suitable for Western blot analysis of infected plants than for ELISA.
\end{abstract}

\section{Introduction}

The Potato mop-top virus (PMTV) is a fungus-transmitted soil-borne virus and the type member of the genus Pomovirus (Torrance and Mayo, 1997). PMTV occurs in potato-growing regions in Europe, North and South America and Asia in cool wet climate causing a wide range of symptoms in haulms and tubers, which vary depending on the potato cultivar and environmental conditions, thus complicating the identification of the virus disease (Jones, 1988).

PMTV has tubular and rigid particles, measuring 18-22 $\times 100-150$ or $250-300 \mathrm{~nm}$ (White et al., 1972) encapsidating three RNA components, namely RNA 1, RNA 2 and RNA 3 (Kallender et al., 1990; Kashiwazaki et al., 1995; Savenkov et al., 1999). The third RNA, $2.9 \mathrm{~kb}$ long, contains a triple gene block (TGB) encoding three proteins involved in cell-to-cell movement, and an additional open-reading frame (ORF) for a predicted 'cystein-rich' protein (CRP) with unknown function (Mayo et al., 1996; Fig. 1).

The analysis of nucleotide sequences showed that PMTV genomes from different parts of the world are highly conserved which is the fact that usually makes the diagnosing of viral disease more simple (Mayo et al., 1996; Sandgren et al., 2001; Nielsen and Nicolaisen, 2003; Čeřovská et al., 2003a; Pečenková et al., 2004). However, the detection based solely on the presence of PMTV coat protein (CP) seems to be insufficient as it was recently shown that the distribution of PMTV RNAs varies in different parts of infected plants and that the multipartite virus PMTV is capable of establishing infection without the CP-encoding RNA, and also without the putative CRP (Savenkov et al., 2003). Thus, detection based on some other non-structural protein could be advantageous when combined with $\mathrm{CP}$ detection methods and polymerase chain reaction (PCR) methods (Arif et al., 1994; Rantanen et al., 1999; Mumford et al., 2000). Antisera raised against triple gene block protein 1 (TGBp1), for example, could be used for such a purpose as well as for studying the fate of this protein in infected plant and its role in the viral movement through plant tissue.

TGB proteins are found in viruses belonging to several different genera. The TGB1 proteins could be generally divided into two groups: Hordeivirus-like TGBp1 and Potexvirus-like TGBp1 (Morozov and Solovyev, 2003). In both cases TGBpls contain a $\mathrm{NTP} /$ helicase sequence domain and belong to helicases of superfamily I (SF-I) with the typical presence of seven conserved motifs (Gorbalenya et al., 1989). Both hordei-like and potex-like TGBp1, like many known helicases, can form homodimers or oligomers and are capable of self-interaction (Gorbalenya and Koonin, 1993; Cowan et al., 2002). TGBp1 of rod-shaped Pomovirus and Hordeivirus are larger comparing with potex-like TGBpls - 39-63 kDa and contain additional long N-terminal domains (Solovyev et al., 1999). The presence of arginine/lysine-rich clusters was found in these extensions as well as the region of sequence similarity upstream of the helicase domain (Solovyev et al., 1999). 


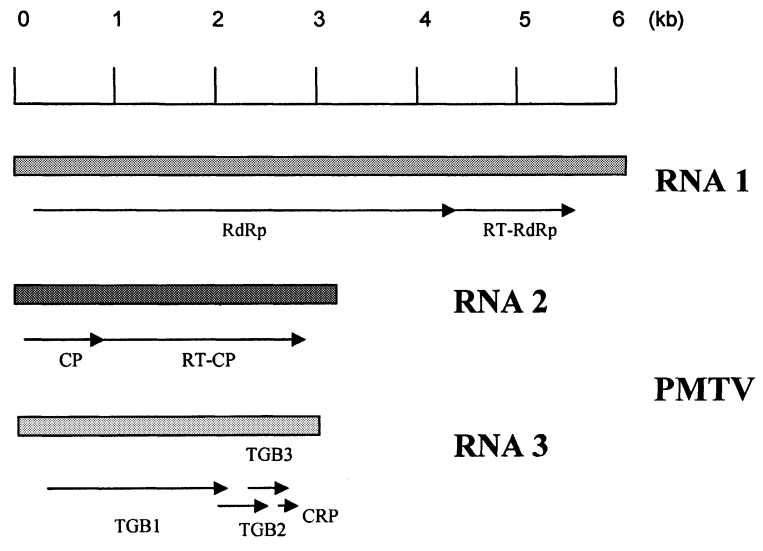

Fig. 1 The tripartite genome of Potato mop-top virus (PMTV). The translation products are represented by arrows. Description of abbreviations used in the Fig. 1 are: RdRp, RNA-dependent RNA polymerase; RT, read-through protein; $\mathrm{CP}$, coat protein; TGB, triple gene block; CRP, cystein-rich protein

Unfortunately, PMTV full-length TGBp1 (463 amino acid, $51 \mathrm{kDa}$ ) was hard to express in its fulllength in bacterial system (Pečenková et al., 2005). Therefore, we decided to examine bacterial expression of TGBpl gene shortened on its $3^{\prime}$-end by two different restriction digestions and to use one of these two constructs for raising rabbit polyclonal antibodies.

\section{Materials and Methods}

Virus source and IC-RT-PCR

The PMTV isolate 54-10 was kindly provided by $\mathrm{Dr}$ Steen Lykke Nielsen from the Danish Institute of Agricultural Sciences, Flakkebjerg, Denmark.

cDNA of PMTV RNAs was obtained by immunocapture reverse transcription (IC-RT) PCR as follows. The tubes were coated with $100 \mu \mathrm{l}$ anti-PMTV immunoglobulin G (IgG; $1 \mu \mathrm{g} / \mathrm{ml}$; Adgen, Auchincruive, Scotland, UK) in coating buffer for $3 \mathrm{~h}$ at $37^{\circ} \mathrm{C}$. The wells were then washed $[3 \times 150 \mu$ l phosphate-buffered saline $(\mathrm{PBS})+\mathrm{T}]$ and $100 \mu \mathrm{l}$ of the homogenate of PMTV-infected leaves in conjugate buffer (1:10) was added. The samples were incubated overnight at $4^{\circ} \mathrm{C}$ and washed again three times with PBS $+\mathrm{T}$. After the final wash the RT and amplification with Superscript II (Gibco, Gaizesburg, MD, USA) and Taq polymerase following manufacturer's recommendations were carried out. The RT and subsequent PCR was performed using PMTV-specific primers (aaccatggaaagcggattcaacggaagt as a sense primer and atagatcttccggaccatacctgtctgttt as an antisense primer), based on the sequence of $\mathrm{Sw}$ isolate available in GenBank database under the accession number AJ277556. The sense and antisense primers have introduced restrictions sites that will be relevant for further experiments, $N c o$ I and $B g l$ II respectively (underlined). The PCR was carried out in 30 cycles: $30 \mathrm{~s}$ denaturation at $94^{\circ} \mathrm{C}, 30 \mathrm{~s}$ annealing at $55^{\circ} \mathrm{C}$ and 1 min elongation at $72^{\circ} \mathrm{C}$.

\section{Cloning procedure}

The $1.3 \mathrm{~kb}$ fragment of interest was cloned to pTZR7T/A (Fermentas, St. Leon-Rot, Germany) using
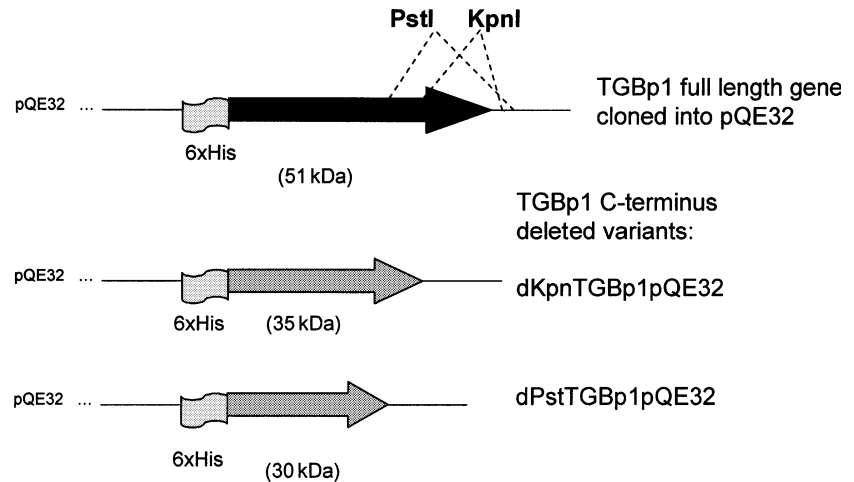

Fig. 2 The two Potato mop-top virus (PMTV) triple gene block protein 1 (TGBp1)-deleted variants that were used for protein production in bacteria. The C-terminus deletions were obtained using Pst $\mathrm{I}$ and $K p n I$ restriction sites located close to $3^{\prime}$-end of TGBpl gene and in $\mathrm{pQE} 32$ polylinker

3'-A overhangs generated by Taq polymerase and then recloned into plasmid pQE32 (Qiagen GmbH, Hilden, Germany) using BamHI and BglII sites, thus equipping the construct with $6 \mathrm{xHis}$ tag. The plasmid was then subjected to two different digestions: Pst I and $K p n I$ digestion, for which the suitable restriction sites were present in the second half of the TGBpl gene as well as in the polylinker of pQE32. In both cases, the $\mathrm{C}$-terminal fragment of several hundred base pairs was cut out (Fig. 2). All molecular cloning procedures were performed according to Sambrook et al. (1989).

\section{Sequencing}

The cloned fragments were sequenced in order to check the integrity of ORF, the presence of $6 x \mathrm{His}$ tag on the $\mathrm{N}$-end of expressed protein and the extent of TGBp1 deletion. The sequencing was performed using an ALFexpressII Sequencer with the AutoRead Sequencing Kit (AP Life Science, Goeteborg, Sweden), using QIAexpress pQE sequencing primers (Qiagen $\mathrm{GmbH}$ ). The sequence analyses were carried out using programs available on EXPASY server (Gasteiger et al., 2003). The deduced amino acid sequence was aligned with the TGBp1 sequence available in GenBank under accession number AY426745 by CLUSTALw (Thompson et al., 1994).

\section{Bacterial expression}

The proteins were expressed and prepared in either standard $(10 \mathrm{ml})$ or large $(500 \mathrm{ml})$ culture of Escherichia coli according to the QIAexpressionist handbook (Qiagen $\mathrm{GmbH}$ ). The protein expression was induced by $0.5 \mathrm{~mm}$ isopropyl-beta-thiogalactopyranosid (IPTG) for $3 \mathrm{~h}$. For expression we used TG1 strain of $E$. coli, which were found to be the most suitable for our experiments.

\section{Polyacrylamide gel electrophoresis in the presence of SDS (SDS-PAGE)}

Deleted variant of TGBp1 was partially purified from $500 \mathrm{ml}$ of the bacterial culture of selected colony. The pellet from $2 \mathrm{ml}$ of bacterial culture was resuspended in $100 \mu \mathrm{l}$ of the Laemmli buffer, boiled for $2 \mathrm{~min}$ and 
aliquots were loaded on $12 \%$ polyacrylamide gel-containing sodium dodecyl sulphate (SDS; Laemmli, 1970). For visualization of the separated proteins Coomassie Brilliant Blue R250 was employed. Both the soluble and insoluble fractions prepared according to Lin and Cheng (1991) were subjected to SDS polyacrylamide gel electrophoresis (PAGE).

\section{Chelating chromatography}

The chromatography was performed on chelating Sepharose Fast Flow (Amersham Biosciences, Piscataway, NJ, USA) charged with $\mathrm{Ni}^{2+}$ ions according to manufacturer's protocol.

\section{Western blot analysis}

The proteins separated by SDS-PAGE were electroblotted to a nitrocellulose membrane $(0.45 \mu \mathrm{m}$, Sleicher and Schuell Protran) in semidry system (OMNITRANS apparatus, Omnibio Brno, Czech Republic) according to Hirano and Watanabe (1990). The membrane was then incubated for $1 \mathrm{~h}$ in $4 \%$ bovine serum albumin (BSA) with PBS and then washed four times with PBS. The recombinant tagged proteins were detected with anti-His antibodies (Amersham Bioscience). The bands of interest were visualized by reaction with a substrate BCIP/NBT (Sigma Aldrich, St. Louis, Missouri, USA) according to Sambrook et al. (1989).

\section{ELISA}

Individual TGBp1 fractions from different steps of the purification process and plant material infected with PMTV were subjected to various types of enzymelinked immunosorbent assay (ELISA); the double-antibody sandwich (DAS)-ELISA followed that of Clark and Adams (1977). The conditions for indirect platetrapped antigen (IPTA) ELISA were performed according to Ceřovská et al. (2003b), in brief.

Plates were coated with antigens diluted in standard coating buffer and incubated overnight at $4^{\circ} \mathrm{C}$. The ELISA plates were washed with $\mathrm{PBS}+\mathrm{T}$ for four times. Commercial antibody $(1 \mu \mathrm{g} / \mathrm{ml})$ or anti-TGBp1 IgG $(5 \mu \mathrm{g} / \mathrm{ml})$ in conjugate buffer were added and incubated for $2 \mathrm{~h}$ at $37^{\circ} \mathrm{C}$. Swine antirabbit IgG conjugated to alkaline phosphatase (SWAR-AP, Sigma Aldrich, St. Louis, Missouri, USA; diluted 1 : 10 000) was added and incubated for $3 \mathrm{~h}$ at $37^{\circ} \mathrm{C}$. Finally, the plates were washed and substrate $(0.1 \mathrm{mg}$-nitrophenyl phosphate per $\mathrm{ml}$ of $0.1 \mathrm{M}$ diethanolamine buffer, $\mathrm{pH}$ 9.8) was added.

\section{Antisera production}

The antisera against the bacterially expressed TGBp1 were prepared in New Zealand rabbits by three subcutaneous and one intramuscular injections of $350 \mu \mathrm{g}$ of electrophoretically purified protein, which was directly cut out from the SDS gel, followed by its comminuting in liquid nitrogen and resuspension in PBS for 3-week interval. The protein was emulsified with an equal volume of Freund's complete adjuvant for the first injection and with Freund's incomplete adjuvant for subsequent two injections. For the last injection the antigen was diluted in PBS. The rabbits were bled 2 weeks after the last injection. The serum fractions were collected and stored at $-20^{\circ} \mathrm{C}$ until required. The immunoglobulin fraction from the antisera was obtained using caprylic acid fractionation (Steinbuch and Audran, 1969) and conjugated to alkaline phosphatase (Avrameas, 1969).

\section{Results}

\section{Designing of C-deleted constructs of TGBp1}

The PCR fragment comprising TGBp1 gene was cloned into pQE32 (Qiagen $\mathrm{GmbH}$ ) using BamHI and $B g$ III sites, thus being equipped with $6 \mathrm{xHis}$ tag. The plasmid was then digested with PstI restriction enzyme that cutting out 520 bp from the $3^{\prime}$-end and with KpnI, cutting out $428 \mathrm{bp}$ from the $3^{\prime}$-end (Fig. 2). After religation and transformation two colonies, namely dKpnTGBp1pQE32 and dPstTGBp1pQE32 were sequenced. The alignment of obtained sequences with the full-length TGBpl gene for the same isolate is illustrated in Fig. 3. Three mutations that appeared during the experimenting are marked in bold as illustrated in Fig. 3. However, according to protein structure prediction we did not expect these mutations to interfere with immunogenic features of antigen.

\section{Expression and purification of PMTV-TGBp1}

Both above-described constructs were used to transform E. coli TG1 and contrary to the full-length TGBp1, the strong protein expression for C-deleted TGBp1 variants was obtained. We selected one of these two constructs, namely dPstTGBp1pQE32 to produce the recombinant protein in large bacterial culture and to purify it (Fig. 4). We tried to purify the protein by means of chelating chromatography using its His-tag. The purified protein was not proved to have the homogenic pattern in analysis. For that reason we decided to use for antibodies raising the electrophoretically purified antigen.

\section{Production of polyclonal antisera to a recombinant PMTV- TGBp1}

For antisera production we used the protein product from the expression vector dPstTGBp1pQE32 transformed to $E$. coli TG1 clone. Antisera were obtained from bleeds taken 2 weeks after the fourth injection. The anti-PMTV-TGBp1 sera had titres of $1 / 2000$ when tested in an indirect ELISA with purified fused protein. Obtained antisera gave strong reaction with homologous recombinant antigen in IPTA-ELISA. No reactions was obtained using DAS-ELISA (data not shown). In DAS-ELISA we were not able to detect the reactions with plant materials, in IPTA-ELISA we obtained significant differences in absorbances between the healthy and infective materials after overnight incubation with substrate (Table 1).

\section{Western blot analysis}

The obtained polyclonal antibodies reacted strongly with the homologous recombinant TGBp1 antigen for 
dPstTGBP1pQE32 dKpnTGBp1pQE32 TGB1p1

dPstTGBP1pQE32 dKpnTGBp1pQE32 TGB1p1

dPstTGBp1pQE32 dKpnTGBP1pQE32 TGB1p1

dPstTGBp1pQE 32 dKpnTGBP1PQE32 TGB1p1

dPstTGBp1pQE32 dKpnTGBP1pQE32 TGB1p1

dPstTGBP1PQE32 dKpnTGBP1pQE32 TGB1p1

dPstTGBD1poE32 dKpnTGBp1pQE32 TGB1p1

Fig. 3 The alignment of the obtained $P s t \mathrm{I}$ and $K p n \mathrm{I}$-deleted triple gene block protein 1 (TGBp1) with the sequence of the full-length TGBp1 available in GenBank (accession number: AY426745, the first 12 amino acids were introduced with primer sequence). The $6 \mathrm{xHis}$ tag and amino acids that differ as a consequence of restriction enzyme digestion are introduced in boxes. Additionally, three mutations that appeared during experiments are marked in boxes as well

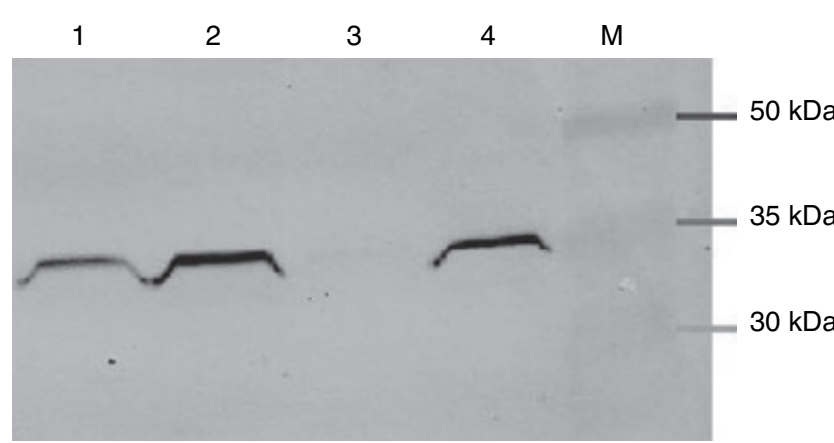

Fig. 4 The bacterial expression of triple gene block protein 1 (TGBp1) construct used for polyclonal antibodies production visualized using anti-His antibodies. Lane 1: bacterial extract from dPstTGBplpQE32 transformed colony before IPTG induction; lane 2: bacterial extract from dPstTGBplpQE32 transformed colony after IPTG induction; lane 3: expression of empty pQE32 plasmid after IPTG induction; line 4: non-soluble fraction of whole cell extract from the colony transformed with dPstTGBplpQE32; lane M: molecular weight marker (Amersham Life Science, Little Chalfont, UK)

Western blot analysis (Fig. 5). The strong band at a position of $\mathrm{M}_{\mathrm{r}}$ of approximately $32 \mathrm{kDa}$ was revealed corresponding to the deduced molecular weight of the
1

50

MRGSHHHHHH GIRLTMESGF NGSRPHRVKK DIDDRVNPVN TQGSSGTTGN MRGSHHHHHH GIRLTMESGF NGSRPHRVKK DILDRVNPVN TQGSSGTTGN

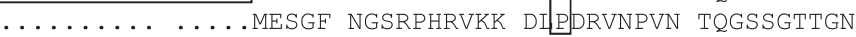

51

100

AFRTNSNKKT QNWKPRSGPG NRNEGDQTKN IKSDLQQPSE VYPEEQVRPE AFRTN SNKKT QNWKPRSGPG NRNEGDQTKN IKSDLQQPSE VYPEEQVRPE AFRTNNNKKT QNWKPRSGPG NRNEGDQTKN IKSDLQQPSE VYPEEQVRPE

101

150

SSTGESVKQQ SEPHRVLEDK KQSGKTAGSS VRIPEEGGGG LGSANYLGKR SSTGESVKOO SEPHRVLEDK KOSGKTAGSS VRIPEEGGGG LGSANYLGKR SSTGESVKQQ SEPHRVLEDK KQSGKTAGSS VRIPEEGGGG LGSANYLGKR

151

QLDFVAKLCV ESGFKSTGKP LKRYPAEFFK SSGLLEKFDR YLSSRLDKGC

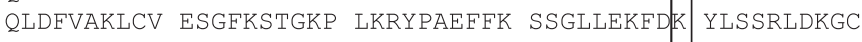
QLDFVAKLCV ESGFKSTGKP LKRYPAEFFK SSGLLEKFDR YLSSRLDKGC

201

250

NLSQRESEVV LKNLRSKRAE QSFLAGAVTG VPGSGKTTLL RKVQCEGGFN NLSQRESEVV LKNLRSKRAE QSFLAGAVTG VPGSGKTTLL RKVQCEGGFN NLSQRESEVV LKNLRSKRAE QSFLAGAVTG VPGSGKTTLL RKVQCEGGFN

251

300

SIVILGNPRS KTEFSNLPSC YTAKEILLLG IAIKCEVLLI DEYTLLTSGE SIVILGNPRS KTEFSNLPSC YTAKEILLLG IAIKCEVLLI DEYTLLTSGE SIVILGNPRS KTEFSNLPSC YTAKEILLLG IAIKCEVLLI DEYTLLTSGE

301 350

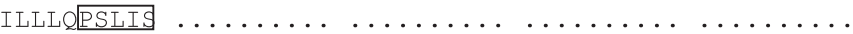
ILLLQKITNS RIVILFGDRA QGSSNTLCSP EWLQVPRVDL OPSLIS.... ILLLQKITNS RIVILFGDRA QGSSNTLCSP EWLQVPVIFQ SLTSRRFGKA

351

$\ldots \ldots \ldots \ldots \ldots \ldots \ldots \ldots \ldots \ldots \ldots \ldots \ldots \ldots \ldots \ldots \ldots \ldots \ldots \ldots \ldots \ldots \ldots \ldots$

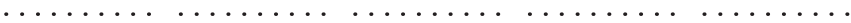
TANLCRRQGF DFEGSEHEDK VVESPYEGSS PPTDINIVFS ESTREDLLEC

401 450

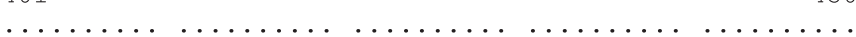

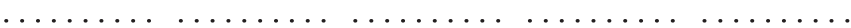
GIESTLVSDV QGKEYNTVTL FIPDEDREYL TNAHLRSVAF SRHKFVLEIR 451 478

$\ldots \ldots \ldots \ldots \ldots \ldots \ldots$

$\ldots \ldots \ldots \ldots \ldots \ldots \ldots \ldots$

CNPELFMOLI NGELASKOOP OTDRYGPE

Table 1

Detection of bacterially expressed PMTV-TGBp1 (BE TGBp1) and TGBpl in infected tissue by means of IPTA-ELISA using IgG produced against recombinant TGBp1

\begin{tabular}{lccc}
\hline & $\begin{array}{c}\text { Commercial } \\
\text { antibodies against } \\
\text { PMTV-CP (Adgen) }\end{array}$ & \multicolumn{2}{c}{$\begin{array}{c}\text { IgG against } \\
\text { BE-CP }\end{array}$} \\
\hline $\begin{array}{l}\text { Buffer } \\
\begin{array}{l}\text { Healthy plants } \\
\text { Nicotiana benthamiana } \\
\text { (dilution 1 : 10) }\end{array}\end{array}$ & $0.20^{\mathrm{a}}$ & \multicolumn{2}{c}{0.20} \\
$\begin{array}{l}\text { PMTV-infected leaves } \\
\text { Nicotiana benthamiana } \\
\text { (dilution 1 : 10) }\end{array}$ & 0.20 & 0.20 & $0.30^{\mathrm{b}}$ \\
PMTV (BE TGBp1; & 0.58 & 0.42 & $1.60^{\mathrm{b}}$ \\
$10 \mu \mathrm{g} / \mathrm{ml})$ & & & \\
\end{tabular}

${ }^{\mathrm{a}} \mathrm{A}_{405}$ values following $60 \mathrm{~min}$ incubation.

${ }^{\mathrm{b}} \mathrm{A}_{405}$ values following overnight incubation.

TGBp1, triple gene block protein 1; PMTV, Potato mop-top virus; ELISA, enzyme-linked immunosorbent assay; IgG, immunoglobulin $\mathrm{G}$; IPTA, indirect plate-trapped antigen.

shortened TGBp1 which was used as an antigen. We did not detect specific reaction with the cells from the culture transformed with the empty pQE32. Our 


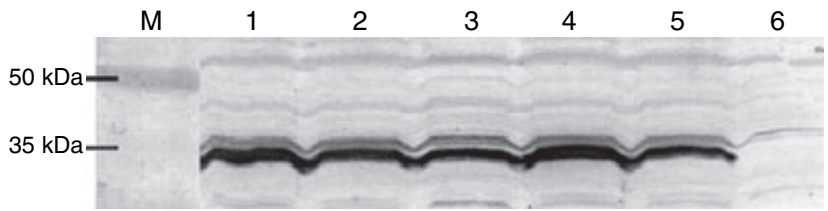

Fig. 5 Western blot analysis of reactivity of anti-triple gene block protein 1 (TGBp1) polyclonal antibodies with homologous antigen. Lanes 1 and 2: bacterial extract from the expression of the colony transformed with dPstTGBplpQE32 construct prior and after induction; lanes 3 and 4: extract from another colony transformed with the same construct; lane 5: non-soluble fraction of whole cell extract from the colony transformed with plasmid with cloned insert from TGBpl gene that was used for polyclonal antibodies production; lane 6: expression of empty pQE32 plasmid after IPTG induction; lane M: molecular weight marker (Amersham Life Science)

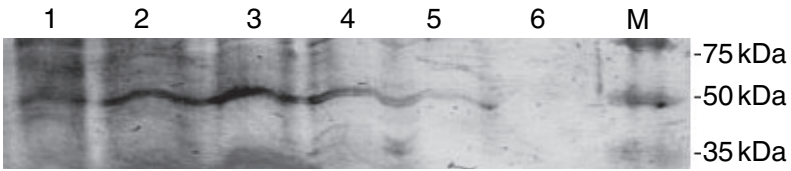

Fig. 6 Western blot of leaf and tuber extracts from Potato mop-top virus (PMTV)-infected Nicotiana benthamiana and Solanum tuberosum visualized using anti-triple gene block protein 1 (TGBp1) antibodies. Lanes 1 and 2: extracts from tubers of two different cultivars of $S$. tuberosum infected with Czech PMTV isolate Korneta-Nemilkov; lanes 3 and 4: leaf extracts from the same samples as in lanes 1 and 2; lane 5: leaf extract from $N$. benthamiana plant infected with PMTV Czech isolate Korneta-Nemilkov; lane 6: healthy $N$. bentha miana control plant; M: molecular weight marker (Amersham Life Science)

antibodies revealed that IPTG non-induced cells produced visible amounts of the antigen.

No reaction was seen with extracts from the leaves of healthy Nicotiana benthamiana plants. The slight reactions were apparent with the leaves of $N$. benthamiana infected with the Danish PMTV isolate 54-10 (faint band at a position corresponding to the $\mathrm{M}_{\mathrm{r}}=50 \mathrm{~K}$ of the complete TGBp1). The stronger reactions were detected with the leaves of $N$. benthamiana infected with the Czech PMTV isolates. The stronger reaction, which was obtained with the heterologous Czech isolate than with the homologous Danish one could be explained with the higher titre of the virus in the Czech isolate. Bands of the same size were found for extracts from PMTV-infected tubers and shoots of $S$. tuberosum (Fig. 6).

\section{Discussion}

We cloned the gene encoding the TGBp1 of PMTV into expression vector $\mathrm{pQE} 32$. In order to obtain strong bacterial expression of TGBp1 protein that seemed to be hard to express in bacteria or was toxic for bacteria, we tried to shorten this gene on its $3^{\prime}$-end by two different restriction digestions. After that efficient and high yield bacterial expression was achieved, as confirmed by SDS-PAGE and Western blot of high range bacterial culture lysate exploiting the presence of $6 \mathrm{xHis}$ tag on the $\mathrm{N}$-terminus of these constructs.

One of these two constructs was used for raising rabbit polyclonal antibodies. The obtained sera and antibodies were tested for the detection of PMTV in laboratory host $N$. benthamiana and natural host Solanum tuberosum by ELISA as well as by Western blots. The obtained antisera have been used successfully for plant virus detection by Western blot analysis and IPTA-ELISA, but they have failed in DAS-ELISA.

According to our expectation the failure to get positive results when the obtained antibodies were used for coating ELISA plates (DAS-ELISA) suggests that our antibodies not only recognize native epitopes, but also epitopes which are affected by some denaturation steps (e.g. binding to the surface of ELISA plates in binding buffer with high $\mathrm{pH}$ or SDS-PAGE in case of Western blot analysis), as this binding may affect their conformation (Korimbocus et al., 2002).

There are few recent reports; however, in which antibodies produced against recombinant viral proteins of Tomato spotted wilt virus (TSWV; Vaira et al., 1996) and Grapevine leafroll-associated closterovirus-3 (GLRaV-3; Ling et al., 2000) were found to be effective in detecting the viruses by DAS-ELISA. Also the study of Petrzik et al. (2001) have demonstrated the successful use of an antiserum against Prunus necrotic ringspot virus (PNRSV) recombinant $\mathrm{CP}$ for the detection of the virus by DAS-ELISA.

Our results confirmed that the antisera produced against recombinant viral proteins were able to detect the viral proteins/antigens of concern by Western blot analysis and IPTA-ELISA but not by DAS-ELISA, what suggested preferential detection of denatured PMTV proteins. These results obtained for TGBp1 were consonant with the former results obtained for antibodies raised against recombinant PMTV-CP (Čeřovská et al., 2003b), and Helias et al. (2003), who obtained only one serum reacting in DAS-ELISA (which gave in comparison with commercial polyclonal antiserum 10 times lower results).

The use of recombinant proteins is an attractive strategy for the production of antibodies against viruses, which are present in low concentrations in infected plants, or are difficult to purify. On the other hand, the use of antibodies against recombinant structural proteins in diagnostic tests seems to be impeded by their inefficiency in recognizing native epitopes. Alternative detection techniques, such as tissue blot immunoassay or DIBA-ELISA, may need to be developed to overcome these difficulties (Korimbocus et al., 2002).

The recombinant viral non-structural proteins expressed in bacterial cells have great potential as a source of antigens for raising specific antibodies. In the case of PMTV this way obtained antibodies could be used as an option for diagnostic purposes because as it was proved previously this virus is able to establish infection without the CP-encoding RNA (Savenkov et al., 2003). Thus, the detection based on some other non-structural proteins could be profitable when combined with other detection methods. Additionally, the benefit of obtaining anti-TGBp1 antibodies for us was their possible application in functional studies of 
the fate of this protein in infected plant and its role in the viral movement through plant tissue.

\section{Acknowledgements}

This research was supported by the grant No. 522/04/1329 of the Grant Agency of the Czech Republic. The authors would like to thank Mmes R. Hadámková, D. Cibochová, J.Kmoníčková and M. Huranová for their excellent technical assistance.

\section{References}

Arif M, Torrance L, Reavy B. (1994) Improved efficiency of detection of potato mop-top furovirus in potato tubers and in the roots and leaves of soil-bait plants. Potato Res 37:373-381.

Avrameas S. (1969) Coupling of enzymes of proteins with glutaraldehyde. Use of the conjugate for the detection of antigens antibodies. Immunochemistry 6:32-52.

Čeřovská N, Moravec T, Rosecká P, Filigarová M, Pečenková T. (2003a) Nucleotide sequences of coat protein coding regions of six potato mop-top virus isolates. Acta Virol 47:41-44.

Čeřovská N, Moravec T, Rosecká P, Dědič P, Filigarová M. (2003b) Production of polyclonal antibodies to a recombinant coat protein of Potato mop-top virus. $J$ Phytopathol 151:1-6.

Clark MF, Adams AN. (1977) Characteristics of the microplate method of enzyme-linked immunosorbent assay for the detection of plant viruses. J Gen Virol 34:475-483.

Cowan GH, Lioliopoulou F, Ziegler A, Torrance L. (2002) Subcellular localisation, protein interactions, and RNA binding of Potato mop-top virus triple gene block proteins. Virology 298:106-115.

Gasteiger E, Gattiker A, Hoogland C, Ivany I, Appel RD, Bairoch A. (2003) ExPASy: the proteomics server for in-depth protein knowledge and analysis. Nucleic Acids Res 31:3784-3788.

Gorbalenya AE, Koonin EV. (1993) Helicases: amino acid sequence comparisons and structure-function relationships. Curr Opin Struct Biol 3:419-429.

Gorbalenya AE, Koonin EV, Donchenko AP, Blinov VM. (1989) Two related superfamilies of putative helicases involved in replication, recombination, repair and expression of DNA and RNA genomes. Nucleic Acids Res 26:4713-4730.

Helias V, Jacquot E, Guillet M, LeHingrat Y, Giblot-Ducray D. (2003) Production of recombinant Potato mop-top virus coat protein in Escherichia coli and generation of antisera recognising native virus protein. $J$ Virol Methods 110:91-97.

Hirano H, Watanabe T. (1990) Microsequencing of proteins electrotransferred onto immobilizing matrices from polyacrylamide gel electrophoresis: application to an insoluble protein. Electrophoresis 11:573-580.

Jones RAC. Epidemiology and control of potato mop-top virus. In: Cooper JJ, Asher MJC (eds), Developments in Applied Biology: II. Viruses with Fungal Vectors, Wellesbourne, Association of Applied Biologists, 1988, pp. 255-270.

Kallender H, Buck KW, Brunt AA. (1990) Association of the three RNA molecules with potato mop-top virus. Neth J Plant Pathol 96:47-50.

Kashiwazaki S, Scott KP, Reavy B, Harrison BD. (1995) Sequence analysis and gene content of potato mop-top virus RNA 3: further evidence of heterogeneity in the genome organization of furoviruses. Virology 206:701-706.

Korimbocus J, Preston S, Danks C, Barker I, Coates D, Boonham N. (2002) Production of monoclonal antibodies to Sugarcane yellow leaf virus using recombinant readthrough protein. J Phytopathol 150:488-494.

Laemmli UK. (1970) Cleavage of structural proteins during the assembly of the head of bacteriophage T4. Nature (London) 227:680-685.

Lin KS, Cheng SY. (1991) An efficient method to purify active eukaryotic proteins from inclusion bodies in Escherichia coli. Biotechnique 11:748-753.
Ling KS, Zhu HY, Jiang ZY, Gonsalves D. (2000) Effective application of DAS ELISA for detection of grapevine leafroll associated closterovirus-3 using a polyclonal antiserum developed from recombinant coat protein. Eur J Plant Pathol 106:301-309.

Mayo MA, Torrance L, Cowan G, Jolly CA, Macintosh SM, Orrega R, Barrera C, Salazar LF. (1996) Conservation of coat protein among isolates potato mop-top virus from Scotland and Peru. Arch Virol 141:1115-1121.

Morozov SI, Solovyev AG. (2003) Triple gene block: modular design of a multifunctional machine for plant virus movement. $J$ Gen Virol 84(Pt 6): 1351-1366.

Mumford RA, Walsh K, Barker I, Boonham N. (2000) Detection of Potato mop-top virus and Tobacco rattle virus using a multiplex real-time fluorescent reverse-transcription polymerase chain reaction assay. Phytopathology 90:448-494.

Nielsen SL, Nicolaisen M. (2003) Identification of two nucleotide sequence sub-groups within Potato mop-top virus. Arch Virol 148:381-388.

Pečenková T, Moravec T, Filigarová M, Rosecká P, Čeřovská N. (2004) Extended sequence analysis of three Danish Potato moptop virus (PMTV) isolates. Vir Genes 29:249-255.

Pečenková T, Filigarová M, Čeřovská N. (2005) Efficient bacterial expression of recombinant potato mop-top virus non-structural triple gene block protein 1 modified by progressive deletion of its N-terminus. Protein Expr Purif 1:128-135.

Petrzik K, Mraz I, Kubelkova D. (2001) Preparation of recombinant coat protein of Prunus necrotic ringspot virus. Acta Virol 45:6163.

Rantanen T, Lehtinen U, Kurppa A. (1999) Development of a IC-RT-PCR Test for Detection of Potato Mop-top Virus. Proceedings of the 14th Triennial Conference of the European Association for Potato Research, Sorento, Italy, p. 547-548.

Sambrook J, Fritsch EF, Maniatis T. Molecular Cloning: a Laboratory Manual, 2nd edn, Cold Spring Harbor, Cold Spring Harbor Laboratory Press, 1989.

Sandgren M, Savenkov EI, Valkonen JP. (2001) The readthrough region of Potato mop-top virus (PMTV) coat protein encoding RNA, the second largest RNA of PMTV genome, undergoes structural changes in naturally infected and experimentally inoculated plants. Arch Virol 146:467-477.

Savenkov EI, Sandgren M, Valkonen JP. (1999) Complete sequence of RNA 1 and the presence of tRNA-like structures in all RNAs of Potato mop-top virus, genus Pomovirus. J Gen Virol 80:27792784.

Savenkov EI, Germundsson A, Zamyatnin AA Jr, Sandgren M, Valkonen JPT. (2003) Potato mop-top virus: the coat protein-encoding RNA and the gene for cystein-rich protein are dispensable for systemic virus movement in Nicotiana benthamiana. $J$ Gen Virol 84:1001-1005.

Solovyev GA, Savenkov EI, Grdzelishvili VZ, Kalinina NO, Morozov SY, Sciemann J, Atabekov JG. (1999) Movement of Hordeivirus hybrids with exchanges in the triple gene block. Virology 253:278-287.

Steinbuch M, Audran R. (1969) The isolation of IgG from mammalian sera with the aid of caprylic acid. Arch Biochem Biophys 34:279-284.

Thompson JD, Higgins DG, Gibson T. (1994) CLUSTAL W: improving the sensitivity of progressive multiple sequence alignment through sequence weighting, position-specific gap penalties and weight matrix choice. Nucleic Acids Res 22:4673-4680.

Torrance L, Mayo MA. (1997) Proposed re-classification of furoviruses. Arch Virol 142:435-439.

Vaira AM, Vecchiati M, Masenka V, Accotto GP. (1996) A polyclonal antiserum against recombinant viral protein combines specifity and versatility. J Virol Methods 56:209-219.

White RF, Kassanis B, James M. (1972) Potato mop-top virus in infected cells. J Gen Virol 15:175-177. 